\title{
Perkembangan Teknologi Informatika dengan Berbagai Aspeknya
}

\author{
Oleh : Jazi Eko Istiyanto
}

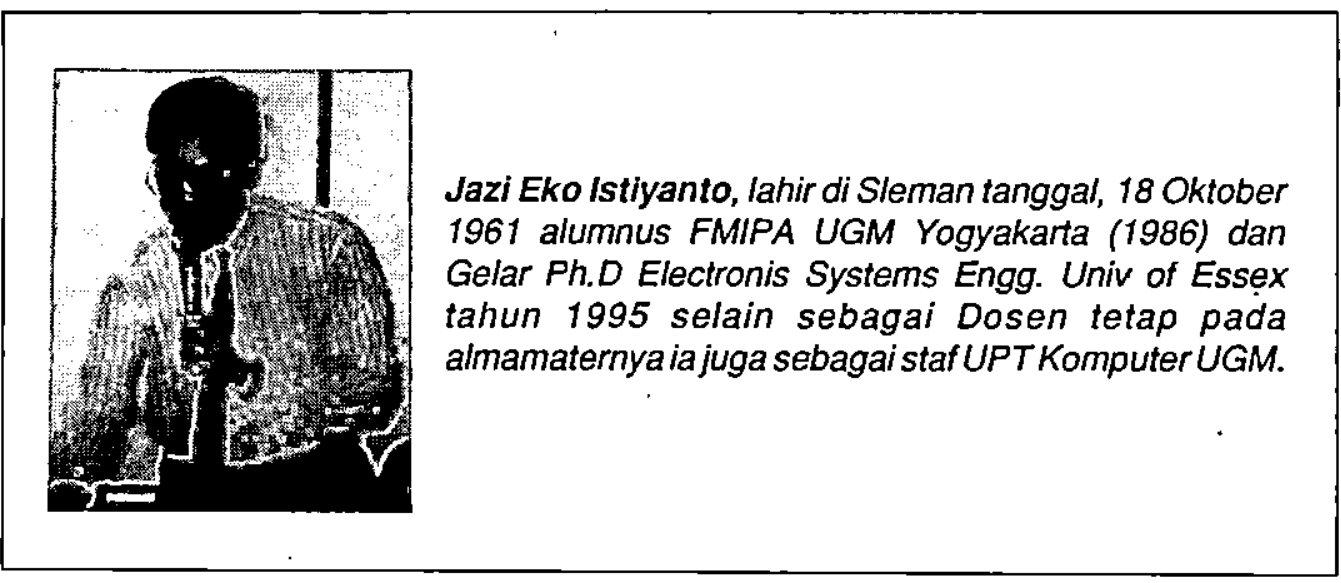

\section{Pendahuluan}

Teknologi informatika sangat luas cakupannya, seḱalipun kita memperoleh kesan bahwa teknologi ini hanya menyangkut perekayasaan perangkat lunak (software engineering). Di dalam pendidikan di Indonesia, teknik informatika berkiblat ke ITB sekalipun kurikulum inti nasional teknik informatika sama persis dengan kurikulum inti nasional.ilmu komputer yang berkiblat ke UI (FASILKOM) ataupun UGM(FMIPA). Di Jerman mereka yang bergelar Dipl. Inform tidak semata-mata menangani software tetapi juga teknologi hardware. Di Canada informatika dan induknya yaitu ilmu komputer umumnya ditangani oleh satu departement (Department of Information and Computer Sciences). Di Amerika nampaknya ilmu komputer lebih dekat ke teknik elektro dengan banyaknya Department of electrical Engineering and Computer Science. Di UK, pemisahan wadah pendidikan sangat jelas antara computer science, information technology, computer engineering, bahkan artificial intelligence, merupakan nama sejumlah jurusan di University of Edinburgh. Di beberapa universitas di UK banyak dikembangkan scheme pendidikan yang berisi $50 \%$ teknologi komputer dan $50 \%$ business dan management (misalnya Information and Business System Technology).

Ilustrasi diatas hanya menunjukkan luasnya cakupan bidang informatika sehingga tugas penyediaan SDM tidak 
mampu dicukupi oleh satu jurusan saja. Realitas ini juga didorong oleh fakta bahwa pada jaman globalisasi informasi ini teknologi informatika menjadi sangat penting peranannya. Ini ditunjukkan dengan kenyataan bahwa komputer PC telah menjadi kebutuhan yang mutlak bagi individu untuk dapat survive dalam persaingan informasi global. Banyak jurusan komputer (terutama di UK) menyelenggarakan program M.Sc conversion yang ditujukan untuk mereka yang menyandang Bachelor bidang apapun.

Berbeda dengan bidang MIS (Management Information System) yang tidak berakar pada ilmu komputer, namun hanya menggunakan komputer sebagai alat teknologi informatika berakar pada teknologi komputer. Oleh karenaitu sejarah perkembangan komputer akan dibahas terlebih dahulu. Kemudian terapan-terapan teknologi informatika yang telah menjadi praktek industri maupun manajemen serta kemungkinan penerapan masa depan akan dibahas. Disebabkan oleh demikian luasnya cakupan teknologi informatika maka hanya beberapa penerapan saja yang dibahas dalam makalah ini.

\section{Sejarah Perkembangan Komputer}

Komputer modem diperlengkapi dengan hardware yang powerful dan software yang ekstensif. Komputer telah mengalami dua tahaputama perkembangan: komputer mekanik dan komputer elektronik. Sebelum 1945, komputer tersusun atas bagian-bagian mekanik dan elektromekanik. Komputer mekanik yang pertama digunakan pada $500 \mathrm{SM}$ dalam bentuk abacus di Cina. Abacus dioperasikan secara manual untuk melaksanakan aritmatika desimal.

Blaise Pascal membuat mesin penjumlah/pengurang mekanik di Perancis pada 1942. Charles Babbage, matematikawan Inggris, merancang mesin diferensial untuk perhitungan polinom pada 1927. Konrad Zuse membuat komputer binerpertama di Jerman pada 1941. Howard Aiken mengusulkan komputer biner elektomekanik pertama yang dibuat oleh IBM pada 1944 dengan nama Harvard Mark-I. Mesin Zuse maupun Aiken dirancang untuk komputasi umum (general purpose).

Berdasarkan teknologi hardware, komputer generasi pertama (1944-54) menggunakan tabung hampa dan memori relay yang saling dihubungkan dengan kabel terisolator. Generasi kedua (1955-64) ditandai dengan pemakaian transistor, dioda, dan teras ferit magnetik, yang saling dihubungkan dengan untai tercetak. Generasi ketiga (1965-1974) mulai menggunakan IC untuk logik maupun memory dalam bentuk small-scale maupun medium-scale integration (SSI dan MSI) dan PCB banyak lapis (multi-layered PCBs). Generasi keempat (1975-1991) memanfaatkan teknologi large-scale maupun very-scale integration (LSI dan VLSI) dan memory semikonduktor menggantikan memori teras. Generasi kelima (1991-sekarang) ditandai dengan pemakaian prosesor dan memory yang merniliki densitas maupun kecepatan tinggi yang didasarkan pada teknologi VLSI yang lebih 'maju. Misalnya, mikroprosesor 64bit dengan 150 Mhz kini dapat dibeli dalam bentuk chip berisi lebih dari sejuta transistor. Dynamic RAM berkapasitas 4 Mbit dan static RAM 256 Kbit kini banyak dipakai di 
dalam komputerberkinerja tinggi.Proyeksi masa depan memprediksikan bahwa 4 buah mikroprosesor akan dibuat dalam suatu chip CMOS tunggal dengan lebih dari 50 juta transistor, dan dyinamic RAM 64 Mbit akan diproduksi secara massal pada dekade berikut.

Komputer generasi kelima baru saja muncul. Komputer ini menekankan aspek massively parallel processing (MPP). Arsitektur yang scalable dan latency-tolerant kini diadopsi oleh sistem MPP menggunakan VLSI, teknologi GaAs, highdensity packaging, dan teknologi optik. Komputer generasi kelima ditargetkan untuk mencapai kinerja Teraflop (sejutajuta operasi floating-point tiap detik) sebelum akhir pertengahan 1990an. Generasi ini diwakili oleh Fujitsu VPP500, Cray Research MPP, Thinking Machine CM-5 dan Intel Paragon,

Telah lama diidentifikasikan bahwa konsep arsitekturkomputertidaklah terbatas pada struktur hardware komputer. Komputer modern tersusun atas hardware, himpunan instruksi, system, software, program aplikasi, dan antarmuka pemakai. Pemakaian komputer untuk masalah riil menurut solusi yang cepat dan akurat. Untuk masalahnumerik bidang sains dan rekayasa, solusinya menuntut formulasi matematika yang rumit dan komputasi integer maupun floating point. Untuk masalah al fanumerik dibidang bisnis dan pemerintah, solusinya memerlukan transaksi yang akurat, manajemen basis data besar, dan operasi pengambilan informasi. Untuk masalah kecerdasan buatan, solusinya memerlukan inferensi logika dan manipulasi simbolik.
Jaringan Komputer Internet

Teknologi komputer yang sedang ramai diperbincangkan adalah teknologi jaringan komputer. Dengan jaringan komputer, jarak geografis menjadi tidak. berarti. Fasilitas yang paling sederhana adalah fasilitas e-mail. Pengguna berkomunikasi dengan pengguna lain melalui fasilitaś surat elektronik ini. Fasilitas e-mail ini telah mempersatukan mahasiswa Indonesia muslim di luarnegeri dengan adanya Islamic Network (dulu berpusat di Wisconsin isnet@mac.wisc.edu, sekarang mungkin di Manitobaís-net@manitoba.edu.ca).Server Islamic Network menyimpan alamat-alamat e-mail anggota net ini. Setiap kali seorang anggota mengirim e-mail ke alamat server, maka e-mail itu direplikásikan ke seluruh anggota net. Diskusi Islamic Network berkisar antara masalah figh (shalat, puasa, jenggot, jilbab, dsb) hingga masalah pengorganisasian bantuan dana untuk kalangan miskin (atau korban bencana alam) di Indonesia. Beberapa anggota bahkan dapat mendirikan sebuah sekolah di Jakarta. Diskusi topik lain tersedia juga seperti pada alt.soc.culture.Indonesia dimana dibahas topik-topik keIndonesiaan. Juga ada kelompok yang membahas masalah teknis misalnya perkembangan baru dibidang kom̄mputer, atau pemanfaatan teknologi tertentu. Ada juga satu kelompok. yang memberikan outlet bagi kekesalan para anggotanya (karena kejenuhan dsb. akibat kerja atau karena ketidakpuasan sistem). Group inimenyediakan net khusus untuk swearing (misuh-misuh).

Dengan fasilitas World Wide Web, lảyánan jaringan menjadilebih banyak. Kita dapat melacak pustaka bahkan di 
perpustakaan universitas di luarnegeri. Kita dapat membaca Time, Newsweek, Republika dsb. melalui fasilitas iṇi. Melalui jaringan komputer, kita bisa mengikuti kursus kebugaran, melihat klip film-film. seperti Indiana Jones, atau bahkan filmfilm porno (X-rated) (Catatan: di beberapa universitas, misalnya di UK, access ke film pomo diblokir:Misal accesske Amsterdam pada server tertentu berarti access ke film porno dan sistem dapat memblokimya. Namun ini tidak menjamin terselenggaranya sensor. Fasilitas film ini tersedia tanpa suara dengan teknologi MPEG. Jaringan komputer global ini merupakan wahana promosi yang cukup potensial: Beberapa univers̀itas, mempunyai home-page yang berisi informasi tentang universitas, jurusan, program studi, riset dsb. Sepengetahuan penulis di dalam WWW tersedia homepage ITB danFMIPA UGM sekalipun tidak resmi dikeluarkan oleh lembaga ybs. tetapi oleh para alumni. Para mahasiswa Pasca Sarjana dapat memanfaatkan WWW untuk melihat dissertation abstract seluruh dunia ataupun melacak pustaka dan konsultasi dengan pakarintemasional.

\section{Telecommuting}

Telecommuting adalah idaman para profesional masa depan. Telecommuting diharapkan memangkas biaya transportasi, meningkatkan efisiensi dan produktivitas kerja, serta lebih "memanusiakan" angkätan kerja dan menurunkan angka kemacetan lalu-lintas.

Pada konsep telecommuting, karyāwan tidak lagi pergi ke kantor, tetapi bekerja di rumah melalui sebuah komputer PC yang terhubung via jaringan komputer ke komputer induk di kantor. Melalui jaringan inilah rapat, pendelegasian tugas, konsultasi dengan manager, dan laporanlaporan dapat saling dipertukarkan. Karyawan dapat bekerja di rumah dan memilih sendiri saat-saat yang merupakan masa produktif baginya (misalnya lebih dekat ke keluarganya dengan mempunyai lebih banyak waktu bagi keluarga. Sementara itu, waktu minum kopi dan mengobrol di kantor (yang umum terjadi di kantor konvensional) dapat ditiadaḱan.

Gaji dapat disetorkan langsung ke rekening bank karyawan. Sementara itu karyawan dapat berbelanja (miulai dari pesan pizzahingga belanja minǵguan) via terminal komputernya.

\section{Standarisasi Software dan User Inter-} face

Mereka yang akrab dengan penggunaan komputer telah lama menyadari bahwa diperlukan waktu yang cukuplama bagi merekauntukmempelajari software baru, bahasa komputer baru, ataupun sistem baru. Pengguna seringkali reluctant untuk berganti sistem. Hal ini telah lama diidentifikasikan oleh para vendor. Gerakan ke arah standarisasi software maupun user-interface telah lama kita sadari. Ini nampak dari layout kunci-kunci keyboard, kemiripan antarperintah-perintah editing Wordstar dengan editor bahasa pemrograman seperti TURBO Pascal, TURBO C. dsb. Yang terbaru adalah pemunculan Windows 95, ataupun pendahulunya yakni Windows 3.1 , maupun Windows 3.1.1. Pada sistem Windows, pengguna yang telah mahir menggunakan suatu paket tidak akan mengalami kesulitan yang berarti dalam menggunakan paket 
Iain. Sebagai contoh, pola menu aplikasi Windows adalah standar: FILE EDIT VIEW INSERT FORMAT TOOLS TABLE...dsb. Di sini FLLE selalu ada disebelah kin diikuti EDIT dan pada EDIT selalau ada fasilitas CUT, COPY, PASTE, UNDO dsb.

\section{Otomatisasi Perkantoran}

Untuk mémbahas otomatisasi perkantoran akan dipakai kasus universitas di luar negeri. Kita ambil contoh layanan perpustakaan. Semua buku ditandai dengan bar-code berisi nama pengarang, klasifikasi buku, judul buku dsb. Anggota perpustakaan juga mempunyai, kartu menggunakan bar-code berisi nama, jurusan, dan tanggal berakhirnya keberlakuan kartu. Proses peminjaman maupun pengembalian dapat dipercepat disebabkan buku dan kartu cukup dibaca làngsung menggunakan bar-code reader. Sepengetahuan penulis Perpustakaan UGM belum memakai fasilitas seperti ini. Dalam taraf ujicoba, Perpustakaan UPT Pusat Komputer UGM telah memanfaatkan metode ini.

Dalam bidang pelaksanaan kuliah, penjadwalan dan lokasi ruang kuliah dapat diotomatisasikan dengan program komputer. Petugas data entry memasukan data-data pada kartu KRS para mahasiswa. Pemasukandata ini tidak perlu sentral tetapi dapat bersifat lokal. jurusan. Berdasarkan rencana studi mahasiswa; diperoleh rekapitulasi jumlah mahasiswa yang mengambil kuliah tertentu. Berdasaŕkan informasi ruang kuliah,maka kuliah-kuliah dapat dijadwalkan menggunakain metodemetode dalam operation research ataupun combinatorial algorithm. Sistem ini memungkinkari dengan mudah mahasiswa mengambil kuliah di jurusan lain dan menjadikan program studi campuran sebagai contoh $50 \%$ ekonomi manajemén dan 50\% teknik informatika) dapat mudah dilak'sanakan.,Sistem ini juga sangat sesuai untuk fakultas/jurusan dan mengakibatkan interaksi mahasiswa antar jurusan menjadi lebih intensif yang membekali mereka untuk bekerjasama kelak sesudah lulus.

Dalam hal pengumpulan tugas PR pemrograman, dosen dapat menulis program uji dan data uji pada terminalnya. Mahasiswa mengumpulkan tugas dengan cara menjalankan suatu program di terminalnyámasing-masing yang membaca data uji maupun program uji yang sudah disiapkan dosen. Cara ini memungkinkan tugas PR diberi nilai secara instantaneous 'dan nilai langsung disimpan ke database dosen ybs. serta mahasiswa dapat segera diberi informasi tentang kesalahankesalahannya.

\section{Mobil Printer}

- Proyek mobil printer saat ini aktif dilaksanakan oleh negara-negaraEropa dan Amerika Serikat. Gagasannya adalah melengkapi pengemudi dengan informasi up-to-date tentang penjaluŕan route terutama kalau terjadi kemacetan jalan, dan sistem auto-pilot kalau sewaktu-waktu pengemudi mengantuk.

Mobil ini tentu saja dilengkapi dengan komputer. Gagasan ini mungkin diilhami oleh file serial Knightrider. Mobil dilengkapi dengan fasilitas Global Positioning System untuk membantu navigasi. Selain itu mobil juga diperlengkapi dengan teropong bidik malam (night vision) yang merubah profit temal sembàrang benda 
menjadi citra visual yang ditunjukkan pada layar pada dashboard. Mobil dapat pula diperlengkapi dengan MIR (Microwave Impulse Radar) yang mengirim dan menerima signal melalui antena berukuran 1 inci. Sebuah transmiter dipasang pada bumper belakang dan mengirim satu juta signal MIR ultra pendek. Bila signal ini menemui suatu dinding atau mobil lain selama pengemudi menggerakan mobil mundur (reverse) maka sebuah alarm akan berbunyi atau bahkan mengaktifkan -rem secara otomatik.

Tekniḳ lain menggunakan kamera video dibawah cermin untuk pandangan belaḱang untuk melihat marka jalan atau mobil lain. Kamera ini memasok data ke sebuah stasiun kerja UNIX dan mengendalikan motor elektrik pada roda stir untuk membelokkan mobil ke kiri ataupun ke kanan.

\section{Reconfigurable Computers}

Reconfigurable computers adalah bidang baru yang mulai aktif digeluti di dunia internasional dan kebetulan merupakan bidang spesialisasi penulis. Komputer jenis ini tersusun atas chip yang dapat diubah-ubah fungsinya. Sistem ini didasarkan pada teknologi Field-programmable Gate Arrays (FPGAs). Jepang sudah mengklaim bahwa dalam beberapa tahun akan memasarkan komputer yang seluruh komponennya terbuat dari FPGAs.

Secara tradisional VLSI chip dihasilkạn dengan mulá-mula méntransformasikan secara manual masalah komputasi ke dalam struktur hardware yang mengimplementasikan masalah komputasi tersebut. Metodologi ini dimulai dengan suatu bagan skematik (dihasilkan dengan menggunakan paket misalnya CADENCE, Mentor GRAPHICS ataupun OrCAD). Bagan skèmatik ini kemudian ditangkap (captured) dan disimulasikan untuk menguji kecocokan fungsional implementasi dengan masalah komputasinya.Selanjutnya dapat dilakukan placement dan routing untuk mendapatkan layout dan layout ini dikirim ke fabrication untuk dibuat chip-nya.

Keahlian, pengalaman, kondisi psikis maupun psikologis disainer sangat berpengaruh pada kualitàs (ekonomi harga, waktu perancangan, maupun keceparan eksekusi) hardware yang dirancang. Selain itu metode capture-and-simulate ini memerlukan turn-around time yang panjang terutama untuk negara yang tidak mempunyai fasilitas fabrikasi VLSI. Di sini disainer juga dibebani dengań rinci implementasi, bukannya dibebaskan untuk mencurahkan daya ciptanya pada segi-segi perancangan yang lebih" menantang kreativitas.

Suatu metodologi describe-andsynthesis dapat mengatasi masalah ini. Komputasi yang. hendak dirancang hardwarenya dapat diungkapkan secara abstrak dengan menggunak an misalnya bahasa VHDL (IEEEE Std. 1076) atau bahasa pemprograman komputer. Teknologi kompilasi berperanan di dalam menangkap, maksud àbstrak ini. Model-model hardware seperti state-diagram, data flow, dan sequencing-graph dapat dimanfaatkan untuk mensintesis hardware yang dikehendaki. Kekuatan utama metodologi describe-and-synthesis terletak pada kemampuan eksplorasi kemungkinan disain, disamping sifatnya yang kurang dependen terhadap kondisi psikis maupun 
psikologis perancang karena dilaksanakan secara otomatik dengan program komputer. Kemampuan eksplorasi ini praktis tidak mungkin dilakukan oleh manusia dalam waktu singkat: Metoda eksplorasi dapat dilakukan dengan model-model graph, dynamic, programming, linier programming, model kombinatorik artificial entelligence, neural network, genetic algorithm dsb. Ini dikombinasikan dengan elemen pokok metodologi ini (dikenal dengan sebutan architectural synhesis hardware synthesis, behavioural synthesis, ataupun high-level synthesis) yakni penjadwalan (scheduling) dan alokasi (allocation) register, unit fungsional, memori dan multiplexer.

Untuk mengatasi ketergantungan terhadap fabrication foundries, reconfigurable systems yang berasal pada FPGA (Field-Programmable Gate Arrays) merupakan pilihan yang cocok sebagai targetuntuksintesis arsitektur.FPGA adalah chip yang dapat direkonfigurasikan oleh pemakai on-site (in-house, in the field). Ia dapat mengimplementasikan circuits yang berbeda pada saat yang berbeda dan arsitektumya sangat berbeda dari EPROM, PLD, PLA, ataupun PAL.

Perkembangan baru dapat dipicu oleh FPGA. Algoritma sintesis arsitektur telah dikembangkan dengan target single VLSI chip implementation. Sebuah PC card yang berisi FPGA + RAM merupakan sistem multi-chip. Keterbatasan pin pada FPGA menyebabkan algoritma-algoritma tersebut kurang berfungsi secara optimal. Ini mengundang solusi pada aras sistem (system-level synthesis) di mana pengelompokkan (clustering) dan pembagian,(partitioning) baik pada aras program maupun pada aras komponen menjadi sangatpenting peranannya. Modelmodel stokastik dan rantai Markov dapat digunakan di sini. Masalah ini juga menyebabkan paradigma object-oriented programming menjadi penting tidak saja dalam software-development namun juga pada permodelan komponen hardware, karena komponen tidak lain adalah obyek.

Reconfigurable computers mempunyai kegunaan

1. Waktu merancang perangkat keras secara otomatik lebih singkat dibanding waktu perancanganmanual oleh insinyur yang berpengalaman sekalipun. .Ini memungkinkan produk perangkat keras dipasarkan sedini mungkin sehingga kompetitif di pasaran.

2. Berbagai alternatif disain dapat dihasilkan dalam waktu singkat. Altematif disain ini umumnya akan memerlukan komponen yang berbeda baik dari segi jenis maupun banyaknya dengan kecepatan eksekusi yang berbeda. Kemampuan eksplorasi disain ini memungkinkan pengguna menyesuaikan secara cepat disain dengan ketersediaan komponen. Manfaat lain adalah sebagai sarana edukatif bagi 'para teknisi perangkat. keras. Bagi perancang berpengalaman, hasil sintesis bisa berperanan sebagai rancangan awal.

3. Struktur perangkat kẹras dapat dihasilkan dari deskripsi watak yang abstrak. Ini memungkinkan insinyur perangkat lunak maupun ilmuwan komputasi dapat pula merancang perangkat keras.

4. Dengan pemanfaatan FPGA, 
implementasi perangkat keras yañg dihasilkan tidak memerlukan penyolderan dan penyambungan dengan kabel, karena FPGA dapat langsung direkonfigurasikan. Ini akan sangat membantu uji prototipe perạngkât keras dengan memperpendek "tum-aroundtime" dan ilmuwan pada umumnya memanfaatkan kapasitas komputasi FPGA.

5. Dalam dunia pendidikan, pengajaran mata kuliah sistem digital dapat dipercepat dengan penggunaan sintesis arsitektur maupun FPGA disebäbkan kemampuan eksplorasi disain dan-sifat rekonfigurabilitas FPGA.

6. Komputasi dalam dunia sains dan rekayasa dapat dibantu dengan FPGA untuk memperoleh kecepatan eksekusi yang hampirmendekati superkomputer. Kinerja superkomputerdapat dikalahkan ) bila dimanfaatkan sintesis arsitektur sebab hardware yang optimal untuk suatu masalah dapat dihasilkan dengan cepat:

\section{Privacy di Era Cyberspace}

Di era cyberspace, privacy manusia : semakin terganggu. Globalisasi informasi. tiđak saja memungkinkan kita mengakses informasi up-to-date dengan cepat dan mudah namun juga bahwa kehidupan pribadi kita telah menjadi milik umum secara global. Ambillah contoh sebagai berikut. Ketika kita mengambil uang pada ATM (Automatic Teller Machine), atau mémbayar dengan kartu VISA di supermarket, berlangganan suatu majalah, atau menggunakan pesawat telepon pribadi maka aktifitas ini tercatat di dalam database komputer. Mereka yang dapat mengakses komputer ini dengan sendirinya mengetahui secara kronologis aktifitas kita, dan juga banyaknya uang yang kita belanjakan,kita berbelanja dimana, majalah apa yang kita baca, nomor telepon berapa saja yang kita "dial" dan' siapa kawănkawan kita. Informasi ini tidak saja berguna bagi para petugas pajak dan tentu saja bank untuk menentukan kredibilitas kita dalam kaitannya dengan permohonan kredit.

Masalah ini menyebabkan bidang internetwork security menjadi sangat penting akhir-akhir ini. Dalam bidang ini tercakup tiga hal yakni:

1. Security attack, yakni suatu tindakan yang mengganggu keamanan infonmasi yang dimiliki oleh suatu organisasi.

2. Security mechanism, yakni suatu miekanisme yang dirancang untuk mendeteksi, mencegah, ataupun mengembalikan keutuhan informasi akibat timbulnya security attack.

3. Security services, yakní suatu layanan yang dipakai untuk mieningkatkan keamanan sistem pengolahan data dan alih informasi pada suatu organisasi.

Banyak dari aktivitas manusia di bidang komersial, kebijakan luar negeri, aksi militer, dan-interaksi personal bergantung pada pemakaian dokumen dan transaksi antar manusia sèringkali banyak bergantung padakonfidensialitas dokumendokumen itu. Dokumen umumnya mempunyai tanda tangan dan tanggal dan mungkin perlu disahkan dengan notaris atau saksi dan perlu disimpan dan dijaga dari campurtangan pihak luar.

Dengan meluasnya penggunaan komputer maka dokumen akan semakin banyak yang disimpan dalam bentuk elektronik. Ini menimbulkan masalah: 
1. Pada dokumen konvensional sangat mudah membedakan antara asli dan fotokopi, sedangkan pada dokumen elektronik sangat sulit untuk membedakan yang asli dari tiruannya.

2. Pada dokumen konvensional perubahan terhadap dokumendapat terlihat dengan jelas. Mengubah elektroniik hanya mengubah bit-bit informasi dan tidak meninggalkan perubahan fisik

3. Dokumen konvensional dapat diautentifikasikan berdasar bentuk tanda tangan misalnya. Dokumen elektronik harus diautentifikasikan berdasarkan bukti-bukti intemal yang ada pada informasi itu sendiri.

Layanan keamanan yang harus disediakan untuk menjaga keamanan suatu sistem komputer (intemet) diantaranya

i. Konfidensialitas yakni dokumen hanya boleh diakses oleh pengguna yang diberi otorisasi.

2. Autentikasi yakni menyakinkan bahwa asal suatu pesan harus diidentifikasikan secara benar.

3. Integritas yakni informasi hanya dapat dimodifikasi oleh pengguna yang diberi otorisasi.

4. Nonrepudiasi yakni bahwa baik pengirim maupun penerima pesan harus tidak bisa memungkiri pengirim/, penerimaannya.

5. Kendali kontrol yakni bahwa akses ke sumberdaya informasi harus dikendalikan oleh atau untuk sistem tar'get.

6. Ketersediaan yakni bahwa aset sistem komputerharus tersedia untuk pengguna yang berotorisasi-kapan saja bila diinginkan.

Banyảk alasan mengapa seseorang dapat bersikap curang terhadap dokumen elektronik

1. Untuk mendapatkan akses terhadap informasi sekalipun secara ilegal.

2. Pura-pura menjadi pengguna lain untuk memindahkan tanggungjawab atau menggunakan lisensi orang lain untuk

a. mengubah-ubah informasi orisinil

b. membuat informasi palsu

c. memakai identitas palsu untuk memperoleh akses legal

d. secara curang dapat melakukan transaksi legal

3. Mengklaim bahwa infonmasi diperoleh dari orang lain padahal dibuat sendiri.

4. Mengklaim telah mengirim pesan yang sebetulnya tidak pernah dikirimkan.

5. Memungkiri penerimaan suatu informasi padahal benar-benarditerima atau mengklaim waktu penerimaan yáng berbeda.

6. Memperbesar jangkau akses ilegal sebagai nampak legal.

7. Mengubah lisensi akses informasi orang lain sehingga dapat memasukkan orang baru ke jangkauan akses atau membatasi jangkauan akses orang lain.

8. Menyembunyikan adanya informasi.

9. Menyisipkan dirinya ke dalam suatu link komunikasi antar-pengguna lain sebagai suatu relay aktif.

10.Mempelajari siapa saja yang mengakses informasi dan kapan akses dilakukán (yakni melakukan generalisasi analisis lalu lintas saluran komunikasi ke basis data).

11. Merusak fungsi softwäre' dengan menambahkan "covert function"

12.Mengakibatkan orang lain melanggar protokol dengan cara mengintroduksikan informasi yang salah. 
13.Merusak konfidensi suatu protokol dengan menimbulkan kesalahan operasi sistem

14. Mencegah terjadinyakomunikasi antar pengguna lain terutama dengan menimbulkan interferensi sehingga komunikasi yang autentik dapat ditolak sebagai tidak autotentik dan sebaliknya.

Contoh-contoh gangguan terhadap sistem komputer adalah adanya interupsi sehingga aset informasi menjadi rusak atau tidak tersedia atau tidak dapat digunakan lagi dengan cara merusak hardware (misal harddisk), memblokir/merusak jalur komunikasi atau menonaktifkan sistem pengelolaan file. Contoh lain adalah intersepsi yang menyangkut "wiretapping" dan mengkopi software pada network. Contoh ketiga adalah modifikasi dengan cara mengubah harga-harga file data, mengubäh program sehingga berkelakuan berbeda, atau mengubah isi pesan yang dikirim via network. Contoh keempat adalah fabrikasi yakni membuat-buat suatu pesan. Contoh-contoh ini dikenal dengan sebutan intruder, virus, dan worm (cacing).

Bidang keamanan komputer ini sedang aktif diteliti. Bidang ini menyangkut pemanfaatan algoritma enkripsi dan dekripsi informasi.

\section{Kesimpulan}

Tulisan ini mencobamengemukakan betapaluasnya aspek teknologi informatika. Oleh karena itu penguasaan teknologi informatika merupakan suatu tugas yang tid̀ak ringan. Indonesia sebagai negara berkembang yang diharapkan memerankan peranan penting setidaknya di Asia
Tenggara telah meletakkan penguasaan teknologi informatika (Pengembangan Sistem Infomasi) dalam point ke 7 usulan kegiatan IPTEK (Program Utama Nasional Riset dan Teknologi 1993) bersama-sama dengan Teknik Produksi, Teknologi, IP Terapan, IP Dasar, Kelembagaan IPTEK, Sarana dan Prasarana IPTEK, dan Statistika. Oleh karena itu sejalan dengan pesatnya perkembangan teknologi informatika, diperlukan strategi mendasar di dalam penentuan prioritas pengembangan teknologi informatika agar dapat kita ikut berperan dan tetap tegak sebagai bangsa di dalam era globalisasi informasi ini. Selain itu pengembangan mental dan moral juga sangat penting dikarenakan untuk survive kita harus juga menjadi pihak yang menghasilkan informast bukan sekedar konsumen informasi.

\section{Daftar Pustaka}

Kai Hwang, 1993, "Advanced Computer Architectur : Paraillelism, Scalability, Programmability", McGraw-Hill Computer Science Series New York.

William Stallings, 1995, "Network and Internetwork Security", Prentice-Hall, Englewood Cliffs, NJ.

David Chaum, 1992, "Achieving Electronic Privacy", Sientific American, August, pp. 76-81.

Sharon Begley, 1995, "Smarl Carl".Newsweek, August 21, pp.50-51.

Jazi Eko Istiyanto, 1995, "The Application of Archilectural, Synthesis to the Reconfiguration of FPGA-base Special Purpose Hardware", Ph.D. Thesis, Depariement of Electronic Engineering, University of Essex. 